\title{
A LIMITAÇÃo MATERIAL DO PODER CONSTITUINTE DERIVADO
}

Recebimento do artigo: 30/01/2008

Aprovado em: 29/02/2008

\section{Sumário}

1 Introdução. 2 Conceituação e origem teórica do poder constituinte derivado. 3 Limitações materiais ao poder constituinte de reforma. 3.1 Limitações explícitas. 3.2 Limitações implícitas. 3.3 Objeções à enunciação expressa de limitações materiais. 4. Prevalência efetiva das limitações materiais ao poder constituinte derivado. 4.1 Teoria da dupla revisão. 4.2 Controle de constitucionalidade. 5 Conclusão. 6 Referências.

\section{Resumo}

O poder constituinte derivado submete-se a limites materiais explícitos e implícitos, cujo propósito é garantir o núcleo essencial da Constituição. E nos estados democráticos de direito, como é o caso do Brasil, a garantia de efetividade desses limites materiais se dá principalmente por meio dos mecanismos de controle de constitucionalidade.

\section{Palavras-chave}

Poder constituinte derivado. Limites materiais. Controle de constitucionalidade.

Revista Mestrado em Direito

\section{Abstract}

Constitutional derived power is subjected to explicit and implicit material limitations, whose purpose is to guarantee the Constitution's essential core. In democratic rule-of-law states like Brazil, the guarantee of effectiveness of these material limitations is given mainly by mechanisms of constitutional control.

\section{Key words}

Constitutional derived power. Material limitations. Constitutional control.

OSASCO, ANO 8, N.1, 2008, P. 31-52 


\section{Introdução}

Este artigo pretende traçar um breve panorama do que vem a ser a limitação material ao poder constituinte derivado e de como tal limitação alcança aplicabilidade, em geral, e em particular no sistema brasileiro vigente. A pertinência do tema ganha relevo por conta do grande número de emendas constitucionais que tem sofrido a Carta de 1998, e da preocupação de que, em tais reformas, seja respeitado o núcleo essencial da Constituição Federal, no qual têm destaque os direitos fundamentais e o regime democrático.

A fim de abordar o tema de um modo mais reflexivo, o trabalho foi estruturado em três blocos que se complementam: o primeiro, que busca conceituar e situar teoricamente o poder constituinte derivado, o segundo, que discorre sobre as várias limitações materiais a esse poder e as objeções à sua necessidade, e o terceiro, que, contrapondo duas ordens de análise e aplicação dessas limitações materiais (a teoria da dupla revisão e o controle de constitucionalidade), busca mostrar o quanto os referidos limites podem prevalecer, ou não, efetivamente na ordem constitucional.

O último bloco trata do cerne da questão, pois permite chegar a uma conclusão realista e crítica sobre a limitação material ao poder constituinte derivado, tema que não é meramente acadêmico, mas que, como já assinalado acima, cada vez mais ganha relevância na vivência político-social contemporânea.

\section{Conceituação e origem teórica do poder constituinte derivado}

O Poder Constituinte, concebido tradicionalmente como poder de organizar juridicamente o Estado, através da edição de normas constitucionais, comporta a distinção fundamental entre poder constituinte originário, que é inicial, autônomo e incondicionado, podendo fazer uma nova Constituição e romper com a ordem anteriormente estabelecida; e poder constituinte instituído, que, justamente por ser criado e regulado pelo originário, é derivado, subordinado e condicionado.

Assim, o poder constituinte é um poder de direito, e não de fato, justamente por ser instituído pelo poder constituinte originário (derivado), que predetermina o seu conteúdo e os seus contornos (condicionado), determinações essas expressas normativamente e às quais ele necessariamente se deve sujeitar (subordinado e limitado). Pressupõe-se que esse poder seja coexistente como uma constituição escrita e rígida.

O poder constituinte instituído, nos estados federais, apresenta duas facetas: o poder constituinte decorrente, pelo qual os estados membros se auto-organizam, editando normas constitucionais próprias, que encontram limites na ordem 
constitucional originária; e o poder de reforma ou revisão constitucional, que se destina a assegurar a adaptação da Constituição estabelecida pelo poder constituinte originário a novas circunstâncias sócio-políticas, o que pressupõe a existência de uma Constituição rígida, a cujos princípios fica sujeito o exercício desse poder de revisão.

Todo o desenvolvimento teórico a respeito do poder constituinte derivado se deu basicamente em torno dessa segunda faceta (poder de reforma), até porque a primeira surgiu historicamente em momento posterior, com o federalismo.

De fato, alguns iluministas eram defensores da imutabilidade da constituição, pois a viam como um triunfo da razão, perfeita, acabada e inquestionável. No entanto, essa tese contrariava a própria dinâmica da vida social e da história, além de incentivar a mudança da ordem institucional unicamente por meio de revoluções.

Conforme assinala Paulo Bonavides ${ }^{1}$, outros tantos teoristas políticos do Iluminismo, como Vattel, Sieyés e Rousseau, admitiam a mudança da constituição, só que sob uma perspectiva estritamente política, o que prejudicava sua factibilidade. Apenas este último, na obra Considerações sobre o governo da Polônia, ofereceu fundamento para a legitimação do conceito jurídico de reforma constitucional realizada por meio de um poder designado pela própria Constituição.

E esse fundamento radicava no princípio de que as leis fundamentais, como é da natureza de todas as leis, são revogáveis, desde que observadas as mesmas formalidades empregadas ao estabelecê-las. Bonavides relata que

\begin{abstract}
o princípio formulado por Rousseau entra na Constituição francesa de 1791, que solenemente reconhece à Nação o direito imprescritível de mudar a Constituição e fazer a reforma daqueles artigos cujos inconvenientes a experiência houvesse demonstrado. Empregar-se-iam para esse fim os meios previstos pela Constituição mesma. Estava assim assentado o princípio jurídico da reforma constitucional por obra do chamado poder constituinte derivado ${ }^{2}$.
\end{abstract}

Nessa idéia também estava implícito o pensamento, exposto com ênfase por Paine e Jefferson, de que uma geração não pode condicionar outra geração em todas as suas escolhas constitucionais.

Porém, a noção da subordinação e, portanto, da limitação desse poder de reforma era bastante forte e arraigada. Tanto que, nos primeiros tempos do

\footnotetext{
${ }^{1}$ BONAVIDES, Paulo. Curso de direito constitucional. São Paulo: Malheiros, 1999, p. 174.

${ }^{2}$ BONAVIDES, Paulo. Curso de direito constitucional. São Paulo: Malheiros, 1999, p. 174; 175. 
34 constitucionalismo moderno, a reforma da constituição foi cercada de numerosas e draconianas limitações.

Apenas com a evolução histórica e com a fundamentação das limitações ao poder constituinte derivado como forma de preservar uma decisão política fundamental de determinada sociedade em determinado momento (como já apontava Carl Schmitt em sua clássica obra sobre a teoria da constituição ${ }^{3}$ ), garantiuse a identidade e a continuidade da constituição como um todo, e passou-se a ter por intangíveis não os textos de determinados artigos da Constituição, mas os princípios contidos por eles. Nessa linha, pode-se afirmar que os dois fundamentos das limitações traçadas ao poder constituinte derivado são a busca da preservação da estabilidade social e institucional, e a imutabilidade relativa da constituição, que não tem dogmas, mas normas.

A legitimidade do poder constituinte derivado repousa na estrita observância dos limites que balizam sua atuação. A preterição total ou parcial desses limites consiste em "fraude à constituição"; se expressos os limites, o seu desrespeito enseja o controle de constitucionalidade da lei reformadora.

Para o objeto de nossa análise neste trabalho, convém fixar a atenção no poder de reforma da constituição, comum a todos os tipos de estado que possuem uma constituição rígida, ao qual incumbe a tarefa de adequação circunstancial dos preceitos constitucionais, e de cujas limitações materiais se ocuparão os itens subseqüentes.

Quanto ao poder constituinte decorrente, ele também sofre limitações materiais análogas às do poder constituinte derivado, sempre no sentido de compatibilizar o arranjo institucional dos estados membros aos "princípios da União", ou seja, à decisão política fundamental da esfera central do Estado, expressa pelo poder constituinte originário.

\section{Limitações materiais ao poder constituinte de reforma}

O exercício do poder de reforma constitucional, no contexto de uma constituição rígida, se dá mediante um processo agravado, que visa dificultar ao legislador ordinário a alteração da lei fundamental, impondo-lhe restrições de ordem temporal, circunstancial, processual e material, uma vez que a limitação é imanente ao poder constituinte instituído. Nesse sentido, as normas de revisão são consideradas uma garantia da Constituição. No entanto, como assinala Canotilho, "as normas de

\footnotetext{
${ }^{3}$ SCHMITT, Carl. Teoria de la constitución. Madrid: Alianza Editorial, 1996. 
revisão não são o fundamento da rigidez da Constituição, mas os meios de revelação

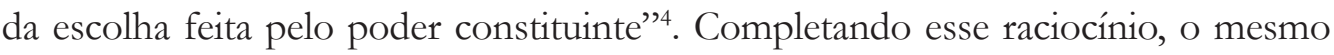
autor citado, em obra conjunta com Vital Moreira, esclarece que

\footnotetext{
a Constituição não só não pode ser infringida por qualquer outra norma, como também não pode ser livremente alterada. Por isso, além de acrescentar ao princípio da primazia, a rigidez constitucional reforça-o, pois o poder legislativo não só tem de respeitar a Constituição, como também não pode alterá-la, livremente e em qualquer momento ${ }^{5}$.
}

As limitações ao poder de reforma constitucional podem, pois, ser distribuídas em quatro grupos: temporais, circunstanciais, processuais e materiais.

Os três primeiros grupos correspondem aos limites formais do poder de reforma e vêm expressamente previstos nas constituições. Um exemplo de limite temporal era a previsão da Constituição imperial brasileira que proibiu sua reforma nos quatro anos posteriores à sua entrada em vigor. Já os limites circunstanciais contemplam algumas circunstâncias durante as quais a constituição não pode ser alterada, como é o caso, na Constituição brasileira de 1988 , do art. $60, \$ 1^{\circ}$, que exclui a possibilidade de emenda na vigência de intervenção federal, de estado de defesa e de estado de sítio. As limitações processuais, ou procedimentais, se traduzem precisamente no processo agravado de tramitação da proposta legislativa de alteração da constituição, o qual varia muito no Direito Comparado, e dizem respeito, basicamente, à restrição da iniciativa do projeto e à exigência de um quórum qualificado para sua aprovação; na Constituição brasileira vigente essas limitações estão previstas no art. 60, I a III, e parágrafos $2^{\circ}, 3^{\circ}$ e $5^{\circ}$.

A maior discussão doutrinária gira em torno dos limites materiais do poder de reforma constitucional, que derivam precisamente da característica de subordinação do poder constituinte instituído, como postulado lógico.

Inicialmente, convém compreender o sentido, o fundamento e o alcance desse tipo de limites, que podem ser explícitos (se expressamente previstos na Constituição) ou implícitos (se, embora não expressamente arrolados no texto da lei fundamental, decorrerem dos princípios e do espírito constitucionais).

\footnotetext{
${ }^{4}$ CANOTILHO, J. J. Gomes. Direito constitucional e teoria da constituição. Coimbra: Almedina, 1997, p. 937.

${ }^{5}$ CANOTILHO, J. J. Gomes; MOREIRA, Vital. Fundamentos da constituição. Coimbra: Coimbra, 1991 , p. 289. 


\subsection{Limitações explícitas}

A idéia de que certas matérias podem ser subtraídas do âmbito de incidência do poder de reforma constitucional, encontra fundamento na necessidade de preservar o arquétipo constitucional, esboçado a partir de uma decisão política da coletividade, mantendo a estrutura básica definida pelo constituinte originário, e traduzida em determinados princípios e institutos. Note-se que, como assinala Manoel Gonçalves Ferreira Filho ${ }^{6}$, não é o poder constituinte (originário ou derivado) que dá fundamento às limitações materiais da constituição, mas sim a decisão política positivada em uma determinada constituição através do poder constituinte originário; ou seja, trata-se de um fundamento político.

É bem verdade que a doutrina tem debatido sobre o real sentido e necessidade de estipular ou identificar esses limites materiais ao poder de reforma, havendo teses que os entendem imprescindíveis, teses que os reputam inócuos diante da realidade político-social, e teses que os entendem superáveis, segundo as circunstâncias. Todavia, esse tipo de debate fica atenuado em vista do fato de que esses limites são uma necessidade lógica nos sistemas de constituição rígida, e uma realidade histórica.

Com efeito, as limitações materiais ao poder de reforma da constituição vêm sendo explicitadas praticamente desde o nascimento do constitucionalismo, uma vez que o primeiro registro da verificação delas está na Constituição americana. No art. IV, $\mathrm{n}^{\circ} 3$, ela garantiu a forma republicana de governo e, no art. V, vedou a supressão, a cada estado membro, do direito de voto no Senado em igualdade com outros estados. Seguiram-se, segundo aponta Jorge Miranda ${ }^{7}$, a Constituição da Noruega (1814), França (1884), Brasil (1891) e Portugal (1911). No século XX, o elenco dos limites materiais explícitos vem se tornando cada vez mais longo, desde a Lei Fundamental de Bonn (1949) até a Constituição portuguesa de 1976 que, inicialmente no art. 290 e hoje no art. 288, contém uma enumeração bastante exaustiva de limites materiais de revisão.

A tendência de aumento, no rol de limites materiais ao poder de alteração da Constituição, cresceu neste século precisamente por causa das experiências autoritárias que ocasionaram graves rupturas constitucionais (como no caso da Alemanha), e do maior comprometimento de certas constituições com programas

\footnotetext{
${ }^{6}$ FERREIRA FILHO, Manoel Gonçalves. Significação e alcance das 'cláusulas pétreas'. Revista de Direito Administrativo, Rio de Janeiro, n. 202, p. 11-17, out./dez. 1995

${ }^{7}$ MIRANDA, Jorge. Manual de direito constitucional. Coimbra: Coimbra , 1988, tomo II, p. 152. 
ideológicos a serem implantados (como a de Portugal, de 1976), visando tornar completamente intangíveis certos princípios que deveriam ser perenizados. $\mathrm{Na}$ verdade, como ressalta Claude Klein, a mera proteção da constituição contra o legislador não é mais suficiente: é preciso protegê-la contra o poder de revisão ${ }^{8}$.

Essas limitações materiais explícitas, usualmente denominadas "cláusulas pétreas”, representam o núcleo intangível de uma Constituição, gravado com uma cláusula de eternidade (em alemão, ewigkeitsgarantien), a fim de conferir uma força especial, frente às eventuais reformas, aos princípios de maior importância na manutenção da decisão política fundamental, base de determinada Constituição. Essas cláusulas de garantia ou de irreversibilidade gozam, como diz Oscar Vilhena Vieira, de uma superconstitucionalidade (no sentido de possuir uma rigidez maior), o que impede que os princípios alçados à condição de cláusulas intangíveis, de serem suprimidos ou desfigurados, podendo apenas ser admitida a sua reestruturação ou ampliação. E por representarem o cerne essencial da Constituição também servem como princípios de interpretação constitucional.

A Constituição brasileira de 1988 expôs seu núcleo imodificável no art. 60, \ $4^{\circ}$, de uma forma proibitiva, dispondo que não será objeto de deliberação a proposta de emenda tendente a abolir (I) a forma federativa de Estado, (II) o voto direto, secreto, universal e periódico, (III) a separação dos Poderes, (IV) os direitos e garantias individuais.

Verifica-se que houve um aumento substancial do rol de limitações materiais explícitas em relação às constituições anteriores (geralmente apenas eram previstas a república e o federalismo). O acréscimo se justifica pela reação ao autoritarismo vivenciado em períodos anteriores e pelo caráter social e compromissário da Carta de 1988; além de se destinar a contrabalançar a flexibilização dos procedimentos ou limites formais de reforma constitucional, introduzida por essa mesma Constituição, segundo ainda Oscar Vilhena Vieira, na instigante obra $A$ Constituição e sua reserva de justiça, através de uma análise político-sociológica?.

\subsection{Limitações implícitas}

Os chamados limites materiais implícitos à reforma constitucional são os que se consideram vedados, ante o silêncio da Constituição, para não lhe destruir o

\footnotetext{
${ }^{8}$ KLEIN, Claude. Théorie et pratique du pouvoir constituant. Paris: Puf, 1996, p. 117; 118. (tradução livre da autora).

${ }^{9}$ VIEIRA, Oscar Vilhena. A constituição e sua reserva de justiça (um ensaio sobre os limites materiais ao poder de reforma). São Paulo: Malheiros, 199, p. 26-29.
} 
espírito ou a coerência, e são deduzidos dos seus princípios fundamentais ${ }^{10}$. Essa teoria foi desenvolvida de início, justamente, frente a constituições omissas ou demasiado sucintas sobre os limites, materiais ao poder de reforma, como a americana.

O precursor do princípio das limitações implícitas foi Sieyès, ao defender que o poder delegado não pode alterar as condições da delegação. Já nos Estados Unidos, Story deduziu da Constituição o limite implícito da vedação de supressão do federalismo; Cooley acrescentou que são limites implícitos ao poder de reforma os que provêm do espírito da Constituição. Contudo, o mais extenso desenvolvimento doutrinário dessa tese se deve a Carl Schmitt, que distinguiu Constituição e leis constitucionais, entendida a primeira como decisão política fundamental, sendo alteráveis apenas as segundas, e na medida em que não desfigurem a primeira.

No Brasil, José Afonso da Silva sustenta que a doutrina vinha admitindo as limitações materiais implícitas ${ }^{11}$, o que, em sua concepção, tende a ser rechaçado na medida em que a Constituição vigente ampliou o rol de limitações materiais expressas, as quais, quando existentes, impossibilitam as limitações implícitas. Contudo, lembrando Nelson de Sousa Sampaio, reconhece que persistem, em nosso ordenamento constitucional, por razões de ordem lógica, três limitações implícitas ao poder de reforma constitucional:

(1) 'as concernentes ao titular do poder constituinte', pois uma reforma constitucional não pode mudar o titular do poder que cria o próprio poder reformador; (2) 'as referentes ao titular do poder reformador', pois seria despautério que o legislador ordinário estabelecesse novo titular de um poder derivado só da vontade do constituinte originário; (3) 'as relativas ao processo da própria emenda', distinguindo-se quanto à natureza da reforma, para admiti-la quando se tratar de tornar mais difícil seu processo, não a aceitando quando vise a atenuá- $1 \mathrm{l}^{12}$.

\footnotetext{
${ }^{10}$ Canotilho designa esses limites de 'textuais implícitos', porque deduzidos do próprio texto constitucional, contrapondo-os aos 'limites tácitos', que decorreriam de uma ordem de valores prépositiva, com força vinculante, e cuja validade como limites materiais de reforma constitucional o referido autor refuta firmemente. (Direito constitucional e teoria da constituição. Coimbra: Almedina, 1997, p. 943; 944). É uma posição razoável, mas somente se considerada do ponto de vista, que ele mesmo ressalta, segundo a qual os limites tácitos ficam excluídos por não guardarem um mínimo de recepção no texto constitucional.

${ }^{11}$ Perfilham essa tese Nelson de Sousa Sampaio, Pontes de Miranda, Pinto Ferreira, Raul Machado Horta, Paulo Bonavides e Zeno Veloso, entre outros.

${ }^{12}$ SILVA, José Afonso da. Curso de direito constitucional positivo. 12. ed. rev. São Paulo: Malheiros, 1996, p. 70 
Quanto a este último item, Zeno Veloso aponta que parte da doutrina

constitucional portuguesa (Gomes Canotilho e Vital Moreira) também admite como limite implícito as regras do próprio sistema de revisão, dando-lhes especial ênfase. Invocando ainda a doutrina alemã, condena a possibilidade da dupla revisão, defendida por Manoel Gonçalves Ferreira Filho, ou seja, da supressão da cláusula pétrea para posterior eliminação do princípio por ela garantido, o que considera de aplicação temerária na realidade política brasileira ${ }^{13}$.

Partindo-se da premissa de que a constituição, mais do que um conjunto de preceitos legais, representa uma decisão política fundamental de determinada sociedade, decorrem logicamente duas conclusões: (a) que a limitação material ao poder constituinte derivado não se dirige a determinados dispositivos constitucionais, mas aos princípios que eles expressam positivamente e (b) que as limitações implícitas suprem omissões compreensíveis da constituição e, portanto, são lógicas e aceitáveis, sendo de difícil definição o seu conteúdo.

Nesse passo cabe mencionar a distinção que Canotilho faz entre limites textuais implícitos (deduzidos do próprio texto constitucional, visto como sistema) e limites tácitos (que são imanentes numa ordem pré-positiva de valores, a qual vincula a ordem constitucional concreta ${ }^{14}$. Dada a dificuldade de deduzir os limites pertencentes a essa segunda espécie, parece que apenas os limites dedutíveis da Constituição poderiam, com sucesso, lograr efetividade na sua função precípua de limitar materialmente o poder constituinte derivado.

\subsection{Objeções à enunciação expressa de limitações materiais}

Como já se fez menção no item precedente, a enunciação expressa de limites materiais ao poder de reforma da constituição não é aceita unanimemente na doutrina e nem mesmo na prática ${ }^{15}$. Porém, a maioria dos autores que a julgam desnecessária parte do raciocínio de que, em face do predomínio dos fatores políticos e históricos, as manifestações do chamado poder constituinte instituído, mesmo que contrárias aos limites expressos que deveria respeitar, acabam prevalecendo.

\footnotetext{
${ }^{13}$ VELOSO, Zeno. Controle jurisdicional da constitucionalidade. Belém: Cejup, 1999, p. 150-152. ${ }^{14}$ Conforme J. J. Gomes Canotilho (Direito constitucional e teoria da constituição. Coimbra: Almedina, 1997, p. 943).

${ }^{15}$ Cármen Lúcia Antunes Rocha, afirma que "constituem minoria as Constituições que estabelecem, expressamente, os limites materiais ao exercício do poder constituinte derivado de reforma", corroborando a assertiva com uma estatística de 1980, que dá conta de que apenas 38 dentre as 142 constituições escritas vigentes no mundo faziam constar esses limites (Constituição e mudança constitucional: limites ao poder de reforma constitucional. Rio de Janeiro: Forense, v. 324, p. 23 a 40). 
Isto é, as limitações materiais expressas não têm geralmente eficácia jurídica, pois, na prática, inexiste diferença substancial entre a manifestação do poder constituinte originário e a do poder constituinte derivado. Isto porque ambos expressam a soberania do Estado e são exercidos, em regra, por uma assembléia representativa do povo, a qual é também o legislador ordinário. Ademais, como não há diferença de conteúdo e hierarquia entre as normas constitucionais originárias, e as supervenientes que integram o mesmo sistema normativo (Constituição), valeria a interpretação segundo a qual não há normas constitucionais inconstitucionais, e também o princípio de que as normas posteriores revogam as anteriores incompatíveis com seu conteúdo.

Neste aspecto, original é a posição do jurista italiano Alessandro Pace ${ }^{16}$, para quem não só os limites materiais implícitos, como também os explícitos, são despiciendos; isso pois, em relação aos primeiros, as tentativas de supressão não encontrariam terreno para ser aprovadas em razão da própria mentalidade política, e, em relação aos segundos, porque a função de conservação dos princípios constitucionais já é assegurada, por definição, pela rigidez constitucional, e não há sentido em atribuir ao órgão reformador uma função que o ordenamento já realiza por outra via.

De qualquer forma, tais objeções acabam cedendo espaço a uma maior previsão de limites expressos nas constituições, postos com o intuito de preservar conquistas institucionais que se têm buscado assegurar através do controle de constitucionalidade, cuja função, nesse particular, será objeto de análise mais detida no capítulo subseqüente.

\section{Prevalência efetiva das limitações materiais ao poder constituinte derivado}

Sob esse aspecto, serão examinados dois aspectos que se contraditam. Ou seja, de início é exposta a teoria da dupla revisão, que, conquanto não condene por completo os limites materiais explícitos, atenua bastante sua persistência e eficácia. Em seguida, realiza-se avaliação de como e em que extensão o controle de constitucionalidade tem contribuído para dar prevalência efetiva às limitações materiais ao poder constituinte derivado.

\footnotetext{
${ }^{16}$ PACE, Alessandro. Potere constituente, rigidità constituzionale, autovincoli legislativi. Padova: CEDAM, 1997, p. 129. 


\subsection{Teoria da dupla revisão}

Essa tese vem defendida coerentemente por Jorge Miranda. Ele parte da premissa segundo a qual os limites explícitos de revisão não são imprescindíveis, pois apenas dão forma aos limites inerentes ao sistema, que são seus princípios essenciais. Então, conclui que estes são passíveis de supressão ou atenuamento pelos procedimentos usuais de alteração constitucional, e nem por isso deixarão de se impor ao poder constituinte derivado.

Ao contrário, se o limite expresso suprimido na verdade não representa um princípio essencial do sistema constitucional, a sua eliminação permite proceder a modificações antes vedadas, a fim de possibilitar a evolução do ordenamento.

Assim, a teoria do duplo processo de revisão relativiza o caráter absoluto dos limites materiais ao poder constituinte. Isso porque, num primeiro momento, retirase da Constituição determinada cláusula de intangibilidade (reforma dos próprios limites ao poder de reforma), o que possibilita que uma alteração posterior ultrapasse o limite anteriormente previsto.

Essa técnica é muito criticada. Canotilho, por exemplo, opõe-se a ela por entender que seria indício de fraude à Constituição, já que tal manobra se constitui numa verdadeira ruptura constitucional. Acrescenta que não há necessidade de se recorrer a esse expediente, pois a impossibilidade da dupla revisão não impede alterações substanciais e legítimas da Constituição.

No entanto, da maneira como enunciada por Miranda, essa teoria não só é lógica, como perfeitamente aceitável, pois permite uma melhor adequação da Constituição aos desígnios do povo, ao qual ela se destina a organizar juridicamente.

É preciso atentar apenas para o fato de que a mudança ou supressão de todos os limites materiais expressos se comunica, imediatamente, a todo o sistema constitucional. Passa, então, a significar uma mudança da própria constituição, ou seja, funciona como manifestação do poder constituinte originário.

E a possibilidade aberta pela teoria da dupla revisão mostra que as limitações materiais expressas não restringem verdadeiramente o poder constituinte derivado, mas valem acima de tudo como limites morais ao poder autorizado a modificar a constituição.

\subsection{Controle de constitucionalidade}

O controle de constitucionalidade, verificação da adequação de um ato normativo aos requisitos formais e substanciais de uma Lei Fundamental, pressupõe 
a existência de uma constituição rígida, cuja supremacia é assegurada por meio desse controle.

Assim, tanto a estipulação expressa de limitações materiais ao poder constituinte derivado (cláusulas pétreas), quanto a fiscalização da constitucionalidade são garantias da Constituição nos estados democráticos de direito.

Predomina, nos vários ordenamentos jurídicos que contemplam o controle de constitucionalidade, o sistema jurisdicional. Por isso se levantaram objeções ao controle ser exercido sobre manifestações do Poder Constituinte, originário ou derivado, que são, em suma, escolhas políticas soberanas que não poderiam ser censuradas pelo Poder Judiciário, sob pena de ser estabelecido um governo dos juízes, o que não encontraria legitimação constitucional.

Por outro lado, a existência de limitações materiais explícitas com caráter de superconstitucionalidade autorizaria rechaçar a objeção precedente. Isto porque elas se constituem em parâmetro objetivo para o controle, chegando-se até a concluir pela possibilidade de reconhecer inconstitucionalidade em normas constitucionais originárias, assim consideradas em relação aos princípios sensíveis da Constituição, expressos nas cláusulas de intangibilidade. É a tese defendida por Otto Bachof na famosa monografia Normas constitucionais inconstitucionais?.

Todavia, essa concepção extremada não prevaleceu nem na doutrina nem na jurisprudência alemãs (apesar de algumas decisões isoladas a terem acolhido), ou mesmo em outros países. Privilegiou-se o princípio da unidade da Constituição, que busca acomodar eventuais incompatibilidades entre os dispositivos constitucionais originários através de técnicas de interpretação; nesse caso não ocorre inconstitucionalidade e, portanto, não se abre a possibilidade para o controle.

Já a reforma constitucional, porque expressão do poder constituinte instituído, encontra limites materiais nas cláusulas pétreas e, se os ultrapassa, incide em vício de inconstitucionalidade, passível de fiscalização judicial. Na expressão de Gilmar Ferreira Mendes, "o controle de constitucionalidade contempla o próprio direito de revisão reconhecido ao poder constituinte derivado" ${ }^{17}$. Explicita mais adiante, a respeito do exemplo alemão:

as cláusulas pétreas são formulações jurídicas destinadas a evitar a destruição ou a radical alteração da ordem constitucional. Constituem, pois, normas de controle (kontrolnorm: kontrollmassstab), que permitem

\footnotetext{
${ }^{17}$ MENDES, Gilmar Ferreira. O controle de constitucionalidade: aspectos jurídicos e políticos. São Paulo: Saraiva, 1990, p. 95. 
aferir a compatibilidade da revisão constitucional. E, somente sob esse prisma, cabe apreciar o controle de constitucionalidade da revisão constitucional $^{18}$.

Trata-se de inconstitucionalidade material, visto que as emendas à Constituição podem incidir também em inconstitucionalidade formal (se desatenderem os procedimentos de reforma) ou ser inexistentes (se, por exemplo, emanarem de órgão ilegítimo para as levar a cabo).

De outro lado, importa assinalar os limites materiais explícitos, especialmente enquanto parâmetros de fiscalização da compatibilidade de uma alteração constitucional com a Constituição, cuja efetividade se busca assegurar em suas linhas mestras. Tais limites devem ser tomados em sentido mais amplo, na medida em que as cláusulas pétreas não se esgotam em preceitos constitucionais determinados, mas representam princípios, subjacentes nos vários dispositivos intangíveis da Constituição, consubstanciando a sua essência. No entanto, como adverte Jorge Miranda,

não decorre, porém, forçosamente, da admissibilidade da figura da inconstitucionalidade material da revisão a admissibilidade teórica ou prática da fiscalização. Tal dependerá de outros factores, o primeiro dos quais vem a ser o sistema de garantia adoptado em cada país ${ }^{19}$.

Admitindo-se, porém, como premissa, a sujeição dos atos de reforma constitucional que violem cláusulas pétreas ao controle de constitucionalidade, cabe perquirir se esse controle pode ser preventivo ou sucessivo, abstrato ou incidental. A rigor, em face da relevância da preservação da integridade da Constituição, do ponto de vista político-institucional, poder-se-ia concluir que qualquer forma de controle é válida. Contudo, o exercício do controle preventivo é de admissibilidade mais delicada, pois o projeto de alteração da Constituição ainda não é ato normativo, e sua promulgação não comporta a possibilidade de veto. Assim, a regra será a sujeição ao controle sucessivo, em especial na via abstrata, pela forte carga política da fiscalização de constitucionalidade nessas hipóteses. Isso não significa, de outro lado, a exclusão do controle na via incidental, sobretudo para a defesa de direitos individuais lesados.

A sanção para o vício de inconstitucionalidade que atinge a alteração constitucional, violadora de cláusulas pétreas, é a nulidade, que opera com efeitos

\footnotetext{
${ }^{18}$ MENDES, Gilmar Ferreira. O controle de constitucionalidade: aspectos jurídicos e políticos. São Paulo: Saraiva, 1990, p. 98.

${ }^{19}$ MIRANDA, Jorge. Manual de direito constitucional. Coimbra: Coimbra, 1988, tomo II, p. 190. 
ex tunc, voltando a vigorar as normas constitucionais suprimidas ou modificadas, como se a alteração que sofreram jamais tivesse ocorrido.

A possibilidade de defender as cláusulas pétreas, através do Poder Judiciário, empresta-lhes um caráter mais dinâmico do que elas inicialmente possuíam, já que visavam apenas manter uma determinada forma de exercício do poder; hoje, além dessa função, elas 'buscam impedir que mudanças constitucionais 'normais' gerem uma erosão dos princípios e valores básicos da Constituição"20. Todavia, a efetividade da garantia visada com o controle de constitucionalidade das cláusulas pétreas depende da coragem com que os juízes encarem o desafio, não se furtando ao exercício rigoroso de tal tarefa.

$\mathrm{Na}$ verdade, uma tensão constante entre o político e o jurídico perpassa a experiência do controle de constitucionalidade das limitações materiais às emendas no direito comparado.

Therezinha L. F. Cunha aponta que "a discussão sobre o problema da inconstitucionalidade da reforma da Constituição foi levantada, de maneira mais concreta, nos Estados Unidos"21, já no século XX. Isto porque, ao longo do século passado, prevalecia a posição de que o controle de constitucionalidade das emendas era uma questão política, impassível de apreciação judicial, pois não se cogitava que o legislador constitucional pudesse ser limitado (tem-se como exemplo dessa fase o caso White vs. Hart, de 1871, em que a Suprema Corte não apreciou a constitucionalidade de emenda invocando a doctrine of the political questions).

Entretanto, no século XX, foi desenvolvida pela própria Suprema Corte uma distinção entre o que se poderia chamar de inconstitucionalidade formal da reforma (matters of procedure), relativa ao procedimento de alteração da Constituição; e a inconstitucionalidade material (matters of substance), referente ao conteúdo da reforma, o que afastava o caráter eminentemente político da questão e abria caminho para uma fiscalização de constitucionalidade das emendas.

De início, todos os julgamentos em cujo mérito do controle das emendas foi enfrentado dizia respeito a aspectos formais do procedimento de reforma, podendo ser referidos, nessa linha, os casos Knight vs. Sheldon, de 1905; Anderson vs. Myers, de 1910; e Glanke vs. Smith, de 1920.

\footnotetext{
${ }^{20}$ VIEIRA, Oscar Vilhena. A constituição e sua reserva de justiça (um ensaio sobre os limites materiais ao poder de reforma). São Paulo: Malheiros, 1999, p. 24.

${ }^{21}$ CUNHA, Therezinha Lucia Ferreira. Poder constituinte e poder de revisão constitucional. O controle da constitucionalidade da emenda constitucional. Revista de Informação Legislativa, Brasília, n. 86, abr./jun. 1985, p. 69.
} 
A inconstitucionalidade material das emendas, porém, até pela ausência de verdadeiras cláusulas pétreas na Constituição americana e pelas dificuldades em definir limites implícitos à sua reforma, continuou a dividir a doutrina e a jurisprudência. O mais acirrado debate doutrinário sobre o tema se deu no início da década de 1920, com a polêmica entre William Marbury, que admitia as limitações materiais ao poder de revisão, as quais, se extrapoladas, acarretavam inconstitucionalidade; e William Frierson, que propugnava ser o Congresso inteiramente livre para reformar a Constituição, não podendo os tribunais verificar a pertinência das emendas constitucionais.

A Suprema Corte só veio a apreciar o primeiro caso de inconstitucionalidade material em 1920, ao julgar os National Probibition Cases (conjunto de casos que questionavam a $18^{a}$ Emenda, a qual instituíra a lei seca). Em decisão sucintamente fundamentada, a Emenda XVIII foi declarada constitucional. O mesmo desfecho teve o caso Lesser vs. Garnett, em que a Suprema Corte apreciou a constitucionalidade material da $19^{\text {a }}$ Emenda, que havia estendido o direito de voto às mulheres.

Optando por declarar a constitucionalidade dessas duas emendas e sem muito fundamentar, a Suprema Corte, com aparente intencionalidade, não aprofundou a análise dessa questão, voltando, a partir da década de 1950, a invocar a doutrina das political questions para se eximir da apreciação da inconstitucionalidade material das emendas.

Já na Alemanha, a Lei Fundamental de Bonn, em seu art. 179, prevê os procedimentos de reforma constitucional, bem como arrola, por remissão aos arts. $1^{\circ}$ e 20 da mesma Carta, as matérias que estão subtraídas do âmbito de atuação do poder revisional. Essas últimas consistem no "núcleo duro" da Constituição de 1949, e são, em síntese, o federalismo cooperativo, os direitos humanos fundamentais, a separação de poderes e o direito de resistência contra a subversão constitucional. Ademais,

a doutrina alemã não admite que se afastem os limites materiais à reforma constitucional através de um sistema de dupla revisão, propondo que só um novo poder constituinte originário é que poderia reformular a questão, modificando as concepções e alterando a cláusula de irrevogabilidade dos bens jurídicos fundamentais ${ }^{22}$.

E o Tribunal Constitucional Alemão (Bundesverfassungsfgericht), provocado em sede de controle abstrato e de controle concreto, não se tem furtado de examinar a constitucionalidade material das emendas à Lei Fundamental. O que ocorre é que,

${ }^{22}$ VELOSO, Zeno. Controle jurisdicional de constitucionalidade. Belém: Cejup, 1999, p. 152. 
até o momento, essa corte nunca declarou nenhuma das emendas questionadas inconstitucionais por violação de cláusulas pétreas, em razão da interpretação restritiva que deu aos princípios constitucionais sensíveis.

Percebe-se nitidamente a autolimitação daquela corte constitucional (aliás muito criticada) que, embora não exclua a possibilidade de declarar a inconstitucionalidade material de uma emenda à Lei Fundamental, procura sempre dar respaldo à decisão política fundamental expressa na emenda (prestigiando o poder constituinte instituído), utilizando-se de uma interpretação conforme à Constituição. O Tribunal Constitucional firmou o entendimento de que as alterações aos princípios garantidos pelas cláusulas pétreas, para incidirem em vício de inconstitucionalidade, têm de atingir o seu cerne, sendo legítimas as alterações fundadas na tutela de outros princípios igualmente relevantes (quiçá até mais), e diante de certas peculiaridades políticas. Apenas o conteúdo essencial de uma cláusula pétrea não pode ser tocado. $\mathrm{Na}$ verdade, como ressalta muito bem Oscar V. Vieira, "a erosão dos direitos ficou à margem da proteção super-rígida oferecida pelo art. 79 (3) da Lei Fundamental"23.

Em Portugal, cuja constituição é abundante em cláusulas pétreas, a doutrina é pacífica em admitir o fenômeno da inconstitucionalidade formal e material das chamadas "leis de revisão constitucional". Quanto à preterição dos limites materiais de revisão, Jorge Miranda ${ }^{24}$ apresenta inclusive um elenco de hipóteses em que ela pode ocorrer, lecionando que

\begin{abstract}
é inconstitucional - materialmente inconstitucional - uma lei de revisão que: a) estabeleça normas contrárias a princípios constitucionais que devam reputar-se limites materiais da revisão, embora implícitos (por exemplo, uma lei de revisão que estabeleça discriminação em razão da raça, infringindo, assim, o princípio da igualdade entre nós agora proclamado no art. $13^{\circ}$ ); b) estabeleça normas contrárias a princípios constitucionais elevados a limites materiais expressos (por exemplo, uma lei de revisão que estabeleça censura à imprensa, afectando, assim, o conteúdo essencial dos direitos, liberdades e garantias dos arts. $37^{\circ} \mathrm{e}$ $38^{\circ}$ ); c) estabeleça normas contrárias a princípios constitucionais elevados a limites materiais expressos, com concomitante eliminação ou alteração da respectiva referência ou cláusula (a mesma hipótese, com eliminação ou alteração da alínea d) do art. $290^{\circ}$ ); d) estipule como limites materiais expressos princípios contrários a princípios fundamentais da Constituição (por exemplo, substituição, na alínea f) do art. $290^{\circ}$, de 'apropriação colectiva' por 'apropriação privada').
\end{abstract}

${ }^{23}$ VELOSO, Zeno. Controle jurisdicional de constitucionalidade. Belém: Cejup, 1999, p. 152.

${ }^{24}$ MIRANDA, Jorge. Manual de direito constitucional. Coimbra: Coimbra, 1988, tomo II, p. 187. 
É pacífica também a admissão do controle de constitucionalidade material da reforma constitucional, seja através da fiscalização concreta, seja da abstrata, de caráter sucessivo, havendo divergências, porém, quanto à admissibilidade do controle preventivo.

$\mathrm{Na}$ verdade, a restrição que o controle preventivo sofre em Portugal está relacionada com o art. 286-3 da Constituição, que prescreve a impossibilidade de recusar promulgação a uma lei de revisão constitucional. Assim, não podendo o Presidente da República vetar a emenda por inconstitucionalidade, o controle preventivo ficaria esvaziado.

Entretanto, o controle sucessivo ou a posteriori das leis de revisão é plenamente aceito, apreciando-se a inconstitucionalidade nos mesmos moldes pelos quais se fiscaliza a inconstitucionalidade das leis infraconstitucionais. E o controle da constitucionalidade ganha um significado extra, essencialmente político, na medida em que, nas palavras de Jorge Miranda ${ }^{25}$,

a fiscalização da constitucionalidade material da revisão serve para atalhar
à pretensão de efetividade da nova Constituição material escondido sob
a forma de revisão, e, se funcionar de facto, esta não virá a formar-se ou
a subsistir.

Não se pode, contudo, perder de vista que o controle das leis de revisão é tão bem aceito em Portugal, justamente pelo caráter dirigente da Constituição de 1976, bem como das revisões periódicas por ela mesma previstas.

No Brasil, o controle de constitucionalidade, formal e material, das emendas à Constituição é de aceitação pacífica na doutrina e mesmo na jurisprudência do Supremo Tribunal Federal - STF.

Entre os autores que o admitem expressamente estão Orlando Bitar, Gilmar Ferreira Mendes, Clémerson Cléve, José Afonso da Silva, Zeno Veloso, Alexandre Moraes, Flávio Novelli e Oscar Vilhena Vieira. Por sua vez, o STF, desde o julgamento do $\mathrm{HC} \mathrm{n}^{\circ}$ 18.178, em 27/09/1926, como assinala Gilmar Ferreira Mendes $^{26}$, deixou assente a possibilidade de apreciar a compatibilidade de emenda constitucional em face da Carta Magna vigente, no caso a de 1891, que tinha por cláusulas pétreas o federalismo, a república e a representação paritária dos estados

${ }^{25}$ MIRANDA, Jorge. Manual de direito constitucional, Coimbra: Coimbra, 1988, tomo II, p. 192; 193.

${ }^{26}$ MENDES, Gilmar Ferreira. Controle de constitucionalidade: aspectos jurídicos e políticos. São Paulo: Saraiva, 1990, p. 104. 
no Senado. Todavia, nesse julgamento, o STF declarou a constitucionalidade da reforma de 1925/1926, levada a cabo durante estado de sítio.

No que tange às cláusulas pétreas, o STF não lhes tem emprestado um caráter de supraconstitucionalidade, de modo a usá-las como parâmetro de controle da adequação das demais normas constitucionais originárias. Ao contrário, tal tese, veiculada na Ação Direta de Inconstitucionalidade (ADIN) n $n^{\circ} 815-3 / \mathrm{DF}$, foi unanimemente rejeitada pelo Pretório Excelso, em julgamento do dia 28/03/96, ao fundamento de que

as cláusulas pétreas não podem ser invocadas para sustentação da tese da
inconstitucionalidade de normas constitucionais inferiores em face de
normas constitucionais superiores, porquanto a Constituição as prevê
apenas como limites ao Poder Constituinte derivado ao rever ou emendar
a Constituição elaborada pelo Poder Constituinte originário, e não como
abarcando normas cuja observância se impôs ao próprio Poder
Constituinte originário com relação às outras que não sejam consideradas
como cláusulas pétreas, e, portanto, possam ser emendadas ${ }^{27}$.

Somente nas ADINs no 926-5/93 e 939-7/93, o STF declarou em sede de controle abstrato sucessivo a inconstitucionalidade de emenda à Constituição, em virtude de ofensa a limites materiais explícitos do poder constituinte derivado. Tratava-se da $\mathrm{EC} \mathrm{n}^{\circ}$ 3/93, que autorizou a instituição, pela União, do IPMF (imposto provisório sobre movimentação ou transmissão de valores e de créditos e direitos de natureza financeira).

$\mathrm{Na}$ ADIN no 926-5, o STF, por unanimidade, reconheceu que o IPMF, ao desrespeitar o princípio da imunidade tributária recíproca, afrontava o princípio federativo, cláusula pétrea desde a Constituição de 1891, e encontra previsão como limite material à reforma constitucional no art. 60, $\ 4^{\circ}$, I, da atual Carta Magna.

E no julgamento da ADIN no $939-7$ se encontra a mais relevante discussão travada, pois o STF teve que explicitar o alcance do art. 60, $\ 4^{\circ}, \mathrm{IV}$, definindo o que devia ser entendido como direito e garantia individual, para fins de proteção com a cláusula de intangibilidade. Apesar da votação não ter sido unânime, foi adotada uma interpretação ampliativa, não circunscrevendo os direitos mencionados no inciso IV aos arrolados no art. $5^{\circ}$ da Constituição. O que implica admitir como parte da doutrina (Raul Machado Horta, por exemplo) vinha propugnando que outras garantias do cidadão podem ser encontradas em outros

${ }^{27}$ ADIN no 815-3/DF, DJU de 10/05/96, p. 15131, Rel. Min. Moreira Alves. 
artigos da Constituição, como o caso do princípio da anterioridade tributária (art. 150, III, "b”), tido por vulnerado pela $\mathrm{EC} \mathrm{n}^{\circ} 3 / 93$. E é importante observar que a maioria dos ministros refutou, com firmeza, o argumento de que essa interpretação lata dos direitos individuais poderia provocar um exagerado engessamento da Constituição.

Contudo, em dois julgamentos posteriores, embora tenha sempre confirmado a possibilidade de efetuar o controle de constitucionalidade de emendas em face das cláusulas pétreas, o STF parece ter-se retraído na sua interpretação ampliativa dos limites materiais de reforma. O primeiro desses julgamentos foi o relativo à introdução da ação declaratória de constitucionalidade no ordenamento brasileiro, por meio da mesma EC n ${ }^{\circ}$ 03/93. Havia sido proposta contra a inovação a ADIN $n^{\circ}$ 913-3, extinta por ilegitimidade ativa. O que não impediu o Supremo de analisar previamente a conformação constitucional da emenda $n^{\circ}$ 03/93, nesse aspecto, por ocasião do julgamento da Ação Declaratória de Constitucionalidade no 1-1. Alegava-se que a ADC suprimia diversos direitos fundamentais, todos previstos no art. $5^{\circ}$ da Constituição; tais direitos não foram considerados atingidos de forma a comprometê-los em sua essência. Assim, a ação declaratória de constitucionalidade teve sua criação declarada constitucional, desde que se assegurasse um mínimo de contraditório em seu processamento e até que uma lei específica viesse a disciplinar esse aspecto, tido por essencial, utilizando-se, pois, o Pretório Excelso de uma espécie de interpretação conforme a Constituição.

O segundo julgamento, proferido em 29/04/99, deferiu medida cautelar na ADIN no 1946-5, na qual se alega que o art. 14 da Emenda Constitucional no $20 /$ 98 vulnera cláusulas pétreas da Constituição brasileira. Aqui, o Tribunal, servindose de solução semelhante à mencionada no parágrafo precedente,

por unanimidade, deferiu a medida cautelar para, dando interpretação
conforme à Constituição ao art. 14 da Emenda Constitucional no 020 , de
15/12/1998, deixar expresso que a citada disposição não se aplica à licença
maternidade a que se refere o art. $7^{\circ}$, inciso XVIII da carta Magna,
respondendo a Previdência Social pela integralidade do pagamento da
referida licença.

Fica claro, pois, o seguinte: se o próprio controle de constitucionalidade das leis já encontra objeções por parte dos defensores da separação rígida de poderes, e dos que questionam a legitimidade democrática da jurisdição constitucional, muito mais delicada é a situação do controle de constitucionalidade das manifestações do poder constituinte instituído. Por isso maioria das cortes constitucionais, através de esforços integrativos, tem privilegiado as decisões políticas expressas nas alterações constitucionais, declarandoas predominantemente compatíveis com o ordenamento, e não violadores dos limites materiais a que necessariamente se sujeitam. 


\section{Conclusão}

A limitação material ao poder constituinte derivado pode ser explícita e implícita. No primeiro caso, é decorrência lógica das constituições rígidas e servem para preservar a identidade constitucional, proscrevendo alterações tão drásticas que cheguem a ocasionar a ruptura da ordem. No segundo caso, decorre do espírito do regime constitucional adotado, até porque, por mais numerosos que sejam os limites expressos, não é possível exaurir esse tipo de normatização; é, portanto, mais fluida.

Os limites materiais expressos não podem ser tão absolutos, de modo a engessarem as escolhas políticas das sucessivas gerações; daí a admissibilidade em tese de interpretações restritivas e mesmo da teoria da dupla revisão. Contudo, são necessários mecanismos para fazê-los efetivos e salvaguardar a constituição de maiorias parlamentares ocasionais; o principal desses mecanismos é o controle de constitucionalidade, cujo parâmetro de controle são as chamadas cláusulas pétreas ou de intangibilidade.

A maioria das cortes constitucionais incumbidas desse controle tem-se autolimitado ao exame da constitucionalidade das alterações constitucionais em face das limitações materiais ao poder constituinte derivado, privilegiando as decisões políticas expressas nessas alterações, com base no respeito à soberania do poder constituinte, quase como se se tratasse de manifestação do poder constituinte originário. No Brasil, o STF tem oscilado no particular, embora já tenha declarado inconstitucionalidade de emenda introduzida em ofensa à limitação material do poder constituinte, mais especificamente emenda que reduzia direitos fundamentais.

De todo o exposto, tendo em conta expressamente essa autolimitação das cortes no controle de constitucionalidade das violações a cláusulas de intangibilidade, além da possibilidade aberta pela teoria da dupla revisão, fica patente que a limitação material ao poder constituinte derivado não tem sido absoluta na prática constitucional, gozando por vezes de uma força mais moral e argumentativa, infelizmente menos efetiva do que parece em um primeiro exame.

\section{Referências}

BONAVIDES, Paulo. Curso de direito constitucional. 8.ed. São Paulo: Malheiros, 1999.

BURDEAU, Georges et al. Droit constitutionnel (manuel). Paris, L.G.D.J, 1997.

CANOTILHO, J. J. Gomes. Direito constitucional e teoria da constituição. Coimbra: Almedina, 1997. 
CANOTILHO, J. J. Gomes; MOREIRA, Vital. Fundamentos da constituição. 51 Coimbra: Coimbra, 1991.

CLÈVE, Clèmerson Merlin. A fiscalização abstrata de constitucionalidade no direito brasileiro. São Paulo: Revista dos Tribunais, 1995.

CUNHA, Therezinha Lucia Ferreira. Poder constituinte e poder de revisão constitucional. O controle de constitucionalidade da emenda constitucional. Revista de Informação Legislativa, Brasília, n. 86, p. 41-76, abr./jun. 1985.

DI RUFFIA, Paolo Biscaretti. Direito constitucional: instituições de direito público. Tradução de Maria Helena Diniz. São Paulo: Revista dos Tribunais, 1984.

FERREIRA FILHO, Manoel Gonçalves. Curso de direito constitucional. 18. ed. rev. e atual. São Paulo: Saraiva, 1990.

Do processo legislativo. 3. ed. atual. São Paulo: Saraiva, 1995.

O poder constituinte. 3. ed. rev. e ampl. São Paulo: Saraiva, 1999.

- Significação e alcance das "cláusulas pétreas". Revista de Direito Administrativo, Rio de Janeiro, n. 202, p. 11-17, out./dez. 1995.

HORTA, Raul Machado. Direito constitucional. 2.ed. rev. atual. ampl. Belo Horizonte: Del Rey, 1999.

KLEIN, Claude. Théorie et pratique du pouvoir constituant. Paris: Puf, 1996.

MENDES, Gilmar Ferreira. Controle de constitucionalidade: aspectos jurídicos e políticos. São Paulo: Saraiva, 1990.

MIRANDA, Jorge. Manual de direito constitucional. 2.ed. Coimbra: Coimbra, 1988. tomo II.

NASCIMENTO, Carlos Valder do. Revisão constitucional: âmbito, alcance e limites. Revista de Informação Legislativa, Brasília, Senado Federal, n. 120, p. 125-145, out./dez. 1993.

NOVELLI, Flávio Bauer. Norma constitucional inconstitucional? A propósito do art. $2^{\circ}, \S 2^{\circ}$, da EC 3/93. Cadernos de Direito Constitucional e Ciência Política, São Paulo, n. 13, p. 18-50, out./dez. 1995.

PACE, Alessandro. Potere constituente, rigidità constituzionale, autovincoli legislativi. Padova: CEDAM, 1997.

ROCHA, Cármen Lúcia Antunes. Constituição e mudança constitucional: limites ao exercício do poder de reforma constitucional.Revista de Informação Legislativa, Brasília, Senado Federal, n. 120, p. 159-186, out./dez. 1993.

SCHMITT, Carl. Teoría de la constitución. Madrid: Alianza Editorial, 1996.

SILVA, José Afonso da. Curso de direito constitucional positivo. 12.ed. rev. São Paulo: Malheiros, 1996. 
52 VELOSO, Zeno. Controle jurisdicional de constitucionalidade. Belém: Cejup, 1999.

VIEIRA, Oscar Vilhena. A constituição e sua reserva de justiça: um ensaio sobre os limites materiais ao poder de reforma. São Paulo: Malheiros, 1999. 